\title{
Social Demography Study of Gonorrhea and Syphilis at RSUD dr. Soedono Madiun
}

\author{
Studi Sosial Demografi Gonore dan Sifilis di RSUD dr. Soedono Madiun
}

\author{
Rahajeng Musy ${ }^{1}$, Vita Widyasari ${ }^{2 *}$, Rosmelia ${ }^{3}$ \\ ${ }^{1}$ Skin and Gender SMF, RSUD dr. Soedono Madiun \\ 2 Universitas Islam Indonesia \\ ${ }^{3}$ Department of Skin and Gender, Universitas Islam Indonesia
}

DATA OF ARTICLE:

Received: 16 Feb 2017

Reviewed: 18 Feb 2017

Revised: 11 Feb 2019

Accepted: 23 Mar 2019

*CORRESPONDENCE:

widyasari.vita@gmail.com

DOI:

10.18196/mm.190227

TYPE OF ARTICLE:

Research

\begin{abstract}
An understanding of the socio-demographic characteristics is the first step to conduct preventive and promotive measures to reduce the number of sexually transmitted infections. This study described the socio-demographic characteristics of gonorrhea and syphilis in dr. Soedono Hospital Madiun. A descripttive study with a quantitative approach used secondary data from outpatient medical records. This research was conducted in dr. Soedono Hospital Madiun, East Java. The sam-ples used in this study were 61 patients who had been diagnosed with gonorrhea and syphilis in the period from July 2013 - June 2016. The data consisted of 50 (82\%) medical records with the diagnosis of gonorrhea and 11 (18\%) medical records with a diagnosis of syphilis. Characteristics of patients/ respondents are the highest age group of $21-30$ years, 22 female patients (36.1\%), 55 male patients $(90.2 \%)$, unmarried status 33 people $(54.1 \%)$, work as private employees 37 people $(60.7 \%)$, pay without insurance 48 people $(78.7 \%)$, and live around Madiun 52 (86.0\%). The socio-demographic factors were dominant in patients with gonorrhea and syphilis in dr. Soedono Hospital period of 2013-2016 was 21-30 years old, male, unmarried, living as private sector employees, pay without insurance, and Madiun origin.
\end{abstract}

Keywords: Gonorrhea; Syphilis; Characteristics; Demography 


\section{INTRODUCTION}

Sexually transmitted diseases are infections whose spread comes from sexual contact from person to person. There are various types of sexually transmitted diseases, depending on the causes, including caused by bacteria ( $\mathrm{N}$. gonorrhoeae, $\mathrm{C}$. trachomatis, T. pallidum), viruses (HSV, HPV, HIV, Herpes B virus, Molluscum contagiosum virus), protozoa (Trichomonas vaginalis), fungi (Candida albicans) and ectoparasites (Sarcoptes scabiei). ${ }^{1}$

Sexually transmitted diseases become a concern in society, especially in developing countries. It was estimated that there are 448 million cases of sexually transmitted diseases because of bacteria in the world in 2005, of which 71 million occurred in the Southeast Asia Region. Based on that number, the highest number of infections was trichomoniasis, with a total of $\mathbf{3 8 . 6}$ million cases. Ranking second to fourth of the infection cases respectively are gonorrhea (22.7 million), chlamydial infection (6.6 million) and syphilis (2.9 million). ${ }^{2}$

The high rate of sexually transmitted infections also has an impact on the financing needed to deal with it. As in the United States, with as many as 19 million cases of sexually transmitted infections, funds are needed around 17 billion US dollars per year for diagnosis, treatment, and education. ${ }^{3}$

Failure or inadequacy in treating sexually transmitted infections can trigger serious complications such as infertility, ectopic pregnancy, anogenital cancer, and premature death, two whereas sexually transmitted infections are preventable diseases.

In dr. Soedono Hospital in Madiun, there are patients with sexually transmitted infections every month, especially gonorrhea and syphilis. As a referral hospital, dr. Soedono Hospital is expected to provide an overview of the social demographic characteristics of gonorrhea and syphilis in East Java.

This study aims to describe the social demographic characteristics of gonorrhea and syphilis in $\mathrm{dr}$. Soedono Hospital, Madiun.

Understanding of the social characteristics of demography is the first step to take preventive and promotive actions to reduce the number of sexually transmitted infections.

\section{MATERIAL AND METHOD}

This study is a descriptive study with a quantitative approach. It used secondary data obtained from the medical records of the patients. This study was conducted in dr. Soedono Hospital, Madiun, East Java. The population used in this study were patients diagnosed with gonorrhea (including urethritis, cervicitis, and gonorrhea proctitis) and syphi- lis period of Juli 2013 - Juni 2016. The samples were taken based on the results obtained by systematic random sampling using the online application at www.random.org.

The variables studied in this study were age, gender, marital status, recent education, occupation, financing, address, sex partner, and a history of previous similar diseases. The instrument used was secondary data (medical records) from dr Soedono Hospital, in the form of stationery and worksheets made by the researcher. The data obtained were analyzed using IBM SPSS version 21 data analysis software with descriptive analysis.

This research has passed the ethical review by the Medical and Health Ethics Committee of the Indonesian Islamic University Medical Faculty on November 3, 2016, with number 04 / Ka.Kom.Et / 70 / KE / XI / 2016.

\section{RESULT}

Data from 61 patients who met the criteria were obtained from outpatient or inpatient care, randomly selected from 214 medical records, 175 with a diagnosis of gonorrhea and 39 with a diagnosis of syphilis. The 61 data obtained consisted of 50 (82\%) medical records with a diagnosis of gonorrhea and 11 (18\%) medical records with a diagnosis of syphilis (Figure 1).

The complete social demographic characteristics of gonorrhea and syphilis patients can be seen in Table 1.

Medical record data obtained in 2013, 2014, 2015, 2016 respectively are 22 (36.1\%), 6 (9.8\%), 21 (34.4\%) and $12(19.7 \%)$. Based on the diagnosis, it appears that the highest visit of gonorrhea patients occurred in 2015, that is as many as 20 patients (40 $\%$ ) of the total of gonorrhea patients. However, it was possible that a similar or higher number can be achieved in 2016 because the number of 9 patients was only counted until mid-year. Whereas

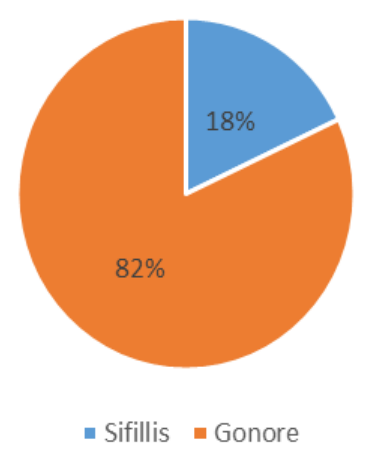

Figure 1. Gonorrhea and Syphilis in the Hospital of dr. Soedono Madiun in 2013-2016 
for patients with a diagnosis of syphilis, the highest number was in 2013 , as many as seven people (63.6 $\%)$ and the lowest was in 2014 where there were no syphilis patients at all.

Nearly all patients (6o medical records or 98.4\%) diagnosed with gonorrhea and syphilis were obtained from the skin and genital outpatient cli nics, only one (or $1.6 \%$ ) medical record data came from the obstetric outpatient and gynecology poly clinic.

The patient's age varies, ranging from the youngest age of 16 years, and the oldest age of 63

Table 1. Demographic Social Characteristics of Gonorrhea and Syphilis Patients

\begin{tabular}{|c|c|c|c|}
\hline Characteristic & Gonorrhea (\%) & Syphilis (\%) & Total \\
\hline \multicolumn{4}{|l|}{ Year } \\
\hline 2013 & $15(68.2)$ & $7(31.8)$ & 22 \\
\hline 2014 & $6(100.0)$ & $0(0.0)$ & 6 \\
\hline 2015 & $20(95.2)$ & $1(4.8)$ & 21 \\
\hline 2016 & $9(75.0)$ & $3(25.0)$ & 12 \\
\hline \multicolumn{4}{|l|}{ Gender } \\
\hline Man & $47(85.5)$ & $8(14.5)$ & 55 \\
\hline Woman & $3(50.0)$ & $3(50.0)$ & 6 \\
\hline \multicolumn{4}{|l|}{ Age } \\
\hline$<21$ years old & $12(85.7)$ & $2(14.3)$ & 14 \\
\hline $21-30$ years old & $17(73.3)$ & $5(22.7)$ & 22 \\
\hline $31-40$ years old & $9(100.0)$ & $0(0.0)$ & 9 \\
\hline $41-50$ years old & $10(83.3)$ & $2(16.7)$ & 12 \\
\hline$>50$ years old & $2(50.0)$ & $2(50.0)$ & 4 \\
\hline \multicolumn{4}{|l|}{ Occupation } \\
\hline Student & $6(100.0)$ & $0(0.0)$ & 6 \\
\hline Entrepreneur & $5(100.0)$ & $0(0.0)$ & 5 \\
\hline Civil Servant & $2(66.7)$ & $1(33.3)$ & 3 \\
\hline Private employees & $31(83.8)$ & $6(16.2)$ & 37 \\
\hline Farmer & $2(50.0)$ & $2(50.0)$ & 4 \\
\hline Jobless & $4(66.7)$ & $2(33.3)$ & 6 \\
\hline \multicolumn{4}{|l|}{ Education } \\
\hline Uneducated & $0(0.0)$ & $1(100.0)$ & 1 \\
\hline Junior High School & $1(50.0)$ & $1(50.0)$ & 2 \\
\hline High School & $3(75.0)$ & $1(25.0)$ & 4 \\
\hline College & $2(100.0)$ & $0(0.0)$ & 2 \\
\hline No information & $44(84.6)$ & $8(15.4)$ & 52 \\
\hline \multicolumn{4}{|l|}{ Region } \\
\hline Madiun Regency & $15(75.0)$ & $5(25.0)$ & 20 \\
\hline Madiun City & $16(100.0)$ & $0(0.0)$ & 16 \\
\hline Magetan & $11(68.8)$ & $5(31.2)$ & 16 \\
\hline Ngawi & $2(66.7)$ & $1(33.3)$ & 3 \\
\hline Others & $6(100.0)$ & $0(0.0)$ & 6 \\
\hline \multicolumn{4}{|l|}{ Marital status } \\
\hline Single & $27(81.8)$ & $6(18.2)$ & 33 \\
\hline Married & $21(80.8)$ & $5(19.2)$ & 26 \\
\hline Widowed & $2(100.0)$ & $0(0.0)$ & 2 \\
\hline \multicolumn{4}{|l|}{ Financing } \\
\hline General & $41(85.4)$ & $7(14.6)$ & 48 \\
\hline BPJS Non PBI & $8(80.0)$ & $2(20.0)$ & 10 \\
\hline BPJS PBI & $1(33.3)$ & $2(66.7)$ & 3 \\
\hline \multicolumn{4}{|l|}{ Similar Treatment History } \\
\hline Yes & $16(80.0)$ & $4(20.0)$ & 20 \\
\hline No information & $34(82.9)$ & $7(17.1)$ & 41 \\
\hline \multicolumn{4}{|l|}{ Religion } \\
\hline Islam & $6(66.7)$ & $3(33.3)$ & 9 \\
\hline No information & $44(84.6)$ & $8(15.4)$ & 52 \\
\hline
\end{tabular}




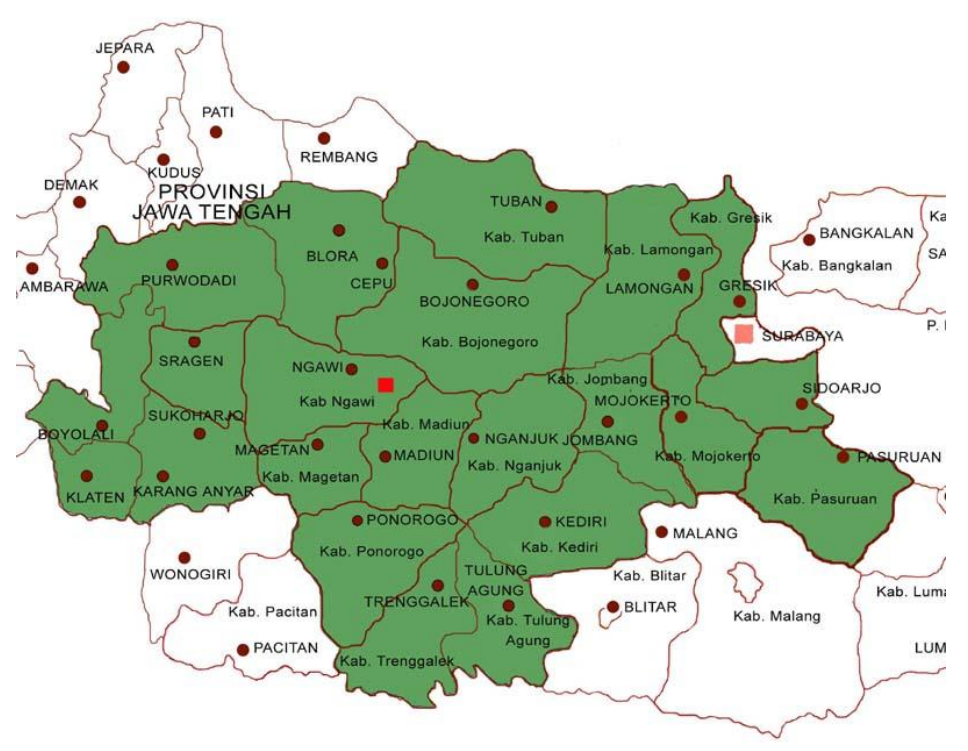

Figure 2. Map of Madiun and Surroundings

years. Of the various age groups, the highest rank was occupied by the age group of 21-30 years, namely 22 patients (36.1\%). Then, it consecutively followed by age groups of <21 years 14 patients (23\%), 41-50 years 12 patients (19.7\%), 31-40 years 9 patients $(14.8 \%)$ and the last, $>50$ years 4 patients (6.6\%).

Gonorrhea and syphilis patients are dominated by men, namely 55 people or $90.2 \%$, while women are only five people or $9.8 \%$. More than fifty percent of gonorrhea or syphilis patients (33 people, 54.1\%) were unmarried. Forty two point six percent or 22 people were married, and the remaining two people, 3.3 percent, were widowed.

The patient's last education status cannot be clearly described because 52 people (85.2\%) did not have the last education status information on their medical records. Of the nine people who had the data; one was out of school (1.6\%), two people graduated from junior high school (3.3\%), four people graduated from high school (6.6\%), and two people graduated from college (3.3\%).

Most of the patients are private employees, as many as 37 people (60.7\%). Second, to last, the percentage is the only slight different. Both are not working, and students are $9.8 \%$ (6 people), followed by entrepreneurs with $8.2 \%$ ( 5 people), farmers $6.6 \%$ (4 people) and finally civil servants $4.9 \%$ (3 people).

The majority of financing is used for out of pocket or general patients, without insurance coverage from any party. $78.7 \%$ (48 people) use this type of financing. Other patients use BPJS insurance, both non-PBI (16.4\%, ten people) and PBI (4.9 $\%$, three people).

The addresses of patients are mostly from the Madiun and surrounding areas, namely Madiun Regency (32.8\%, 20 people), Madiun City (26.6\%, 16 people) and Magetan (26.6\%, 16 people). The other minority is from various regions in Java, such as Bandung, Karanganyar, Malang, Ngawi, Pemalang, Ponorogo, and Wonogiri. It appears on the map of Madiun (Fig. 2) that the majority of sufferers are from the area around RSUD Soedono Madiun.

A history of sexual partners cannot be explored due to limited data. From the data available, sexual history also shows various results. Five patients admitted that they had more than one sex partner. There is also a male patient who has samesex sex (MSM / Men Sex with Men). Also, there is a female patient whose husband as a night club worker.

Twenty (32.8\%) patients with gonorrhea and syphilis treatment admitted to having been ill or treated with similar complaints, the rest of the patients did not have definite, unclear written data, either had never experienced a similar complaint or had no information.

\section{DISCUSSION}

Diagnosed gonorrhea is around 62 million cases worldwide. ${ }^{4}$ Gonorrhea is the second most common disease for sexually transmitted infections in the United States and the United Kingdom (UK). ${ }^{4,5}$ According to the Center for Disease Control and Prevention (CDC), 350.062 gonorrhea cases were reported in the United States in 2014. This number has increased by $5.1 \%$ since 2013 , and $10.5 \%$ since $2010 .{ }^{5}$ Whereas in the UK, 25,525 cases of uncomplicated gonorrhea infection were diagnosed in UK clinics in 2012 and 1905 cases in Scotland. This number has continued to decline since 2002 but 
suddenly increased significantly in 2008 , which was allegedly due to better diagnostic tools. ${ }^{4}$

In 2000 and 2001, reported cases of primary and secondary syphilis were 2.1 cases per 100,000 population, the lowest level since reporting began in 1941. However, syphilis cases increase almost every year from 2000-2001. In 2014, a total of 19.999 cases of syphilis were reported, and national syphilis rates increased to 6.3 cases per 100.000 population, the highest level reported since 1994 in the United States. ${ }^{6,7}$

In this study, both gonorrhea and syphilis sufferers, the highest age of patients were in the age range of 21-30 years, followed by the age range of fewer than 21 years. This is also in line with various previous studies. The research on Gonorrhea sufferers in RSUD Al-Ihsan Bandung in 2015 described that the age of young adults - 18-24 years, most affected compared to other age ranges, followed by the adult age range (24-40 years). ${ }^{8}$ Distribution of age of new gonorrhea sufferers Division of URJ Sexually Transmitted Diseases Skin and Genital Diseases of RSU Dr. Soetomo Surabaya in the 2002-2006 period was not much different from this study, namely the highest age range at the age of $25-44$ years, as many as $52.6 \%$, followed by the age range of $18-24$ years as much as $41.7 \%{ }^{9}$ In Bangladesh, the highest age range of patients is 16-25 years (66.66\%), ten while the average age of gonorrhea patients in Singapore in men is 18 years. ${ }^{11}$ Adults and young people have a higher risk than other age groups due to a combination of various factors, including habits, biology, and culture. For example, economic capacity, shame about selfexamination, and cultural norms that limit them to protect themselves, such as buying condoms. ${ }^{12}$ The majority of male sufferers are in line with various previous studies, as in the study at Bandung, ${ }^{8}$ Surabaya, ${ }^{9}$ Rome ${ }^{13}$ and Bangladesh. ${ }^{10}$ This male dominance is closely related to homosexual behavior. ${ }^{14}$ Most gonorrhea and syphilis sufferers are unmarried; this phenomenon is in line with the results of a study, in which $58.33 \%$ of patients diagnosed with unmarried gonorrhea in Bangladesh. ${ }^{10}$ Many factors influence this phenomenon, including the tendency to have more than one sex partner, employment status, and also closely related to faith. ${ }^{15}$ A history of sexual partners is the most important contribution to gonorrhea patients. Risk factors for contracting gonorrhea include new sex partners, sex partners of more than one person, sex partners having sexually transmitted infections, not always using condoms, having sexually transmitted infections, being in isolated environments such as military camps, race and being in a high-risk environment. ${ }^{5}$ In the UK, the group most at risk for this di- sease is men who have sex with men (58\%). In this study, a history of sexual partners could not be reported because it was not written.

This study has several limitations. The first limitation is that not all patients with a diagnosis of gonorrhea or syphilis come from laboratory results, but only based on clinical diagnosis. Second, for some indicators such as education, history of sexual partners, and a history of similar previous illnesses, it is not written entirely and clearly in the medical record, so it cannot be reported.

\section{CONCLUSION}

This study concludes that the dominant social demographic factors in gonorrhea and syphilis patients in RSUD Soedono in 2013-2016 are men aged 21-30 years, unmarried, have a senior high school education, work as private employees, pay without insurance and from surrounding Madiun.

The suggestions for further research are patients who are taken as a diagnosis sample of gonorrhea and syphilis need to be derived from laboratory results, not only based on clinical diagnosis.

\section{REFERENCE}

1. WHO. Sexually transmitted infections. 2019. Diakses dari https://www.who.int/news-room/factsheets/detail/sexually-transmitted-infections-(stis)

2. WHO. Management of sexually transmitted infections: regional guidelines. 2011.

3. Sevgi OA, Kevin A. F, Lipshutz JA. The New Public Health and STD/HIV Prevention Personal, Public, and Health Systems Approaches. New York: Springer; 2013.

4. Sherrard J. Gonorrhoea. Medicine. 2014; 42 (6): 323-326.

5. Morgan MK, Decker CF. Gonorrhea. Disease-aMonth, 2016; 62 (8): 260-268.

6. Sukthankar A. Syphilis. Medicine, 2014; 42 (7): 394-398.

7. CDC. Sexually Transmitted Diseases Surveillance: Syphilis. 2014.

8. Rahmawati A, Djajakusumah TS, Hikmawati D. Angka Kejadian, Karakteristik, dan Pengobatan Penderita Gonore di RSUD Al-Ihsan Bandung. In: Prosiding Pendidikan Dokter, 2015; 1 (2): 526 531.

9. Jawas FA, Murtiastutik D. Penderita Gonore di Divisi Penyakit Menular Seksual Unit Rawat Jalan Ilmu Kesehatan Kulit dan Kelamin RSU Dr. Soetomo Surabaya Tahun 2002-2006 (Gonorrhea Patients in Sexually Transmitted Diseases Division, Dermato Venereology Department of Dr. Soetomo. Berk Ilmu Kesehat Kulit Kelamin, 
2008; 20 (3): 217-228.

10. Farah A, Mh R, Rahman O. Socio-Demographic Study of Gonorrhoea and Syphilis in Two Medical College Hospital and Two Private Chamber in Bangladesh. Medicine Today, 2013; 25 (01): 18-20.

11. Boon R, Lim T, Wong ML, Cook AR, Brun C, Chan RKW. Determinants of Chlamydia, Gonorrhea, and Coinfection in Heterosexual Adolescents Attending the National Public Sexually Transmitted Infection Clinic in Singapore. Sex Transm Dis, 2015; 42 (8): 450-456.

12. Centers for Disease Control and Prevention. STDs in Adolescents and Young Adults. https://www.cdc.gov/std/stats16/adolescents.ht m. Published in 2017. Accessed September 8, 2018.
13. Bjeki M, Vlajinac H, Sipeti S. Characteristics of Gonorrhea and Syphilis Cases Among the Roma Ethnic Group in Belgrade, Serbia. Braz J Infect Dis, 2016; 20 (4): 349-353.

14. Putu N, Nirmalasari C, Adiguna S, Made N, Puspawati D. Prevalensi dan Karakteristik Infeksi Menular Seksual di Klinik Anggrek UPT Ubud II pada Bulan Januari - Desember 2016. Jurnal Udayana Medika, 2018; 7 (4): 169-175.

15. Finer LB, Darroch JE, Singh S. Sexual Partnership Patterns as a Behavioral Risk Factor for Sexually Transmitted Diseases. Fam Plann Perspect, 1999; 31 (5): 228. 